\title{
Analýza poruch pomocí Power BI
}

\author{
David Ženíšek ${ }^{1}$, Michal Šimon ${ }^{1}$ \\ 1 Západočeská univerzita v Plzni, Fakulta strojní, Katedra průmyslového inženýrství a \\ managementu \\ Univerzitní 8, 306 14, Plzeň, Česká republika \\ zenisek@kpv.zcu.cz \\ simon@kpv.zcu.cz
}

\begin{abstract}
Anotace: Tento článek popisuje př́padovou studii využití nástroje Power $\mathrm{BI}$ od Microsoftu $k$ analýze poruch strojů ve výrobě. Článek nejprve představí nástroj Power $\mathrm{BI}$, následně uvede data, která jsou v podniku generována a se kterými se bude pracovat. Nakonec bude představeno řešení, vytvořené $v$ Power $B I$ sloužící $k$ automatizované analýze a reportingu dat.
\end{abstract}

\section{1 Úvod}

Podnikové informační systémy jsou komplexní a pro běžného uživatele neflexibilní nástroje, jejichž doprogramováni je velmi nákladné. Mnohým uživatelům umožňují pouze generování dat, ve formě .csv či .xlsx, ze kterých si pak sám musí vytvářet analýzy, což může být velmi náročné a čas konzumující. Řešením takových problémů pro mnohé průmyslové podniky může být Power $\mathrm{BI}$, nástroj sloužící $k$ analýze a reportingu dat. Právě na Power BI si v této případové studii představím možnost využití tohoto nástroje na reportingu a analýze poruch strojů ve výrobě.

\section{Power BI}

V oblasti Business Intelligence $(\mathrm{BI})$ dochází $v$ dnešní době ke změnám a inovacím. Objevují se nástroje, se kterými zvládne i běžný uživatel vytvářet a sdílet pokročilé analýzy a vizualizace, bez znalosti programování. A právě jedním takovým nástrojem, kterému se dostává nejlepšího hodnocení, je Power BI. Tento „samoobslužnýc BI nástroj od společnosti Microsoft, umožňuje nahrávat, upravovat a analyzovat data, vytvářet interaktivní reporty a vizualizace a následně je exportovat či sdílet. Že je právě Power BI špičkou v své oblasti potvrzuje fakt, že je společností Gartner oceňován jako nejlepší nástroj v oblasti BI. 


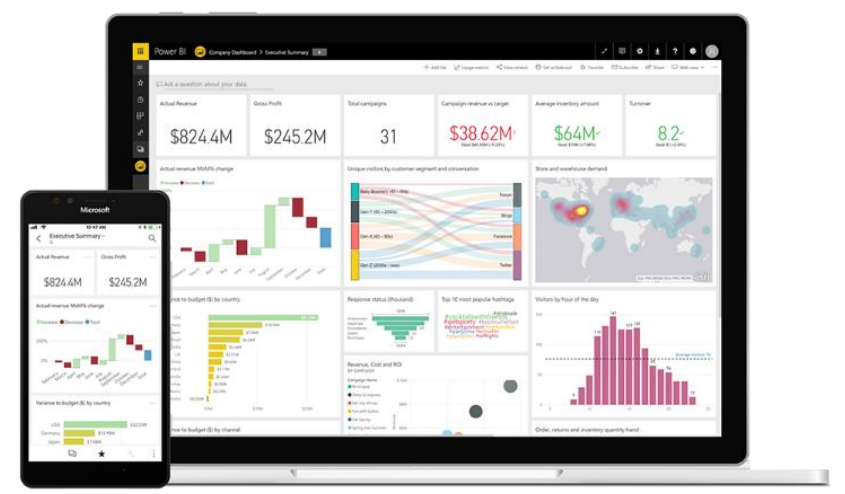

Obrázek 1 - Power BI [1]

\subsection{Prvky Power BI}

Power BI se skládá ze tří základních prvků, kterými jsou Windows aplikace Power BI Desktop, online služba Power BI a mobilní aplikace pro Windows, iOS i Android zařízení. Díky těmto třem prvkům je možné jak vytvářet, tak i sdílet vizuály nebo sestavy (tj. kolekce vizuálů). Zpưsob používání závisí na potřebách jednotlivců, které se odvijí od jejich pozice ve společnosti, týmu nebo jednotlivých projektech a pracovní náplni. Samotný Microsoft na svých stránkách dělí využití Power BI pro koncového uživatele, návrháře sestav, správce a vývojáře. [1]

\subsection{Možnosti Power BI}

Pomocí Power $\mathrm{BI}$ se Ize jednoduše připojit $\mathrm{k}$ mnoha různým zdrojům dat. Je tedy nepravděpodobné, že by se vámi vybraná data $\mathrm{k}$ analýze a následnému zpracování nedala načíst. Mezi často používané zdroje dat se řadí:

- $\quad$ Soubory - .excel, .pdf, .csv, .xml, .txt a dalších.

- Databáze a servery - SQL, Oracle, SAP, IBM databáze a další.

- Power Platform - služby Power BI.

- $\quad$ Azure - balíčky služby Azure.

- Online služby - Google, Facebook, Twitter, Seznam analytics a další aplikace.

- Další - Web a jiné.

Navíc, je možné připojit se staticky, data automaticky pravidelně aktualizovat nebo se připojit živě. [2]

Po nahrání (případně připojení) dat je možné data upravit a očistit pomocí editoru Power Query. Velmi jednoduše zde provádět základní úpravy jako například použití prvního řádku tabulky jako záhlaví, rozdělení a přidání sloupce, nahrazení hodnot nebo změna datového typu. Hravě zde také zvládnete pokročilejší úpravy, jako například sloučení a připojení tabulek, tvorba nového sloupce pomocí funkce a další. $V$ rozšířeném editoru Ize pak i vytvářet vlastní kód pro strukturování dat. 


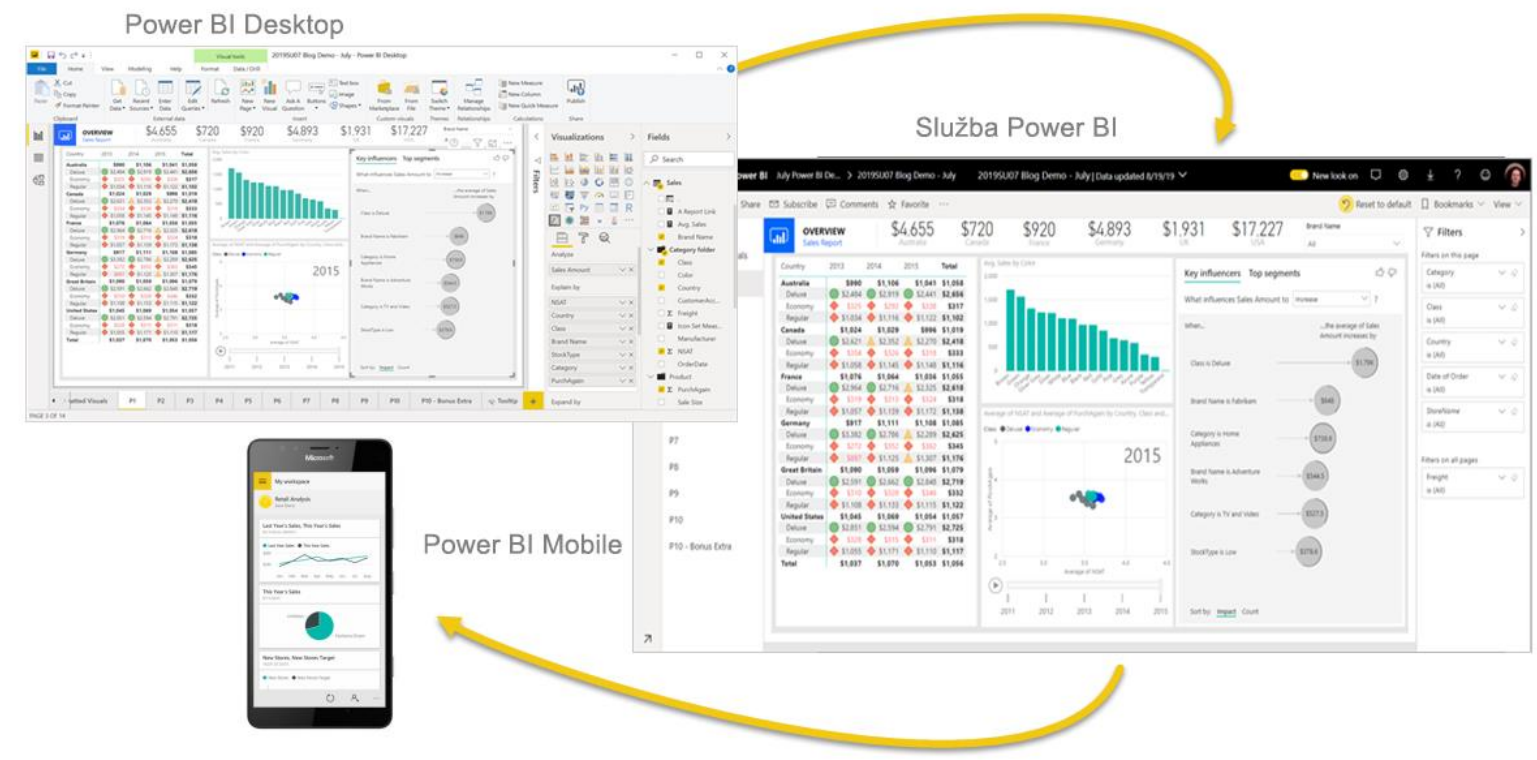

Obrázek 2 - Power Bl [3]

Vytvořené vizuály jsou interaktivní a vzájemně propojené. Je možné v nich jednoduše filtrovat, třídit dle hierarchie a podobně. Vytvořené sestavy pak můžete jednoduše nahrát na web, sdílet emailem, exportovat do .pdf či Excelu, prípadně tisknout. Navíc je možné posílat notifikace například při změně KPI pod určitou úroveň.

Využití Power BI nezná mezí. At' už se jedná o HR, prodej, management či výrobu, Power BI umožňuje sledování zásadních ukazatelů a to i v reálném čase. Lze monitorovat např.:

- využití strojů,

- náklady a zisky,

- účinnost procesů,

- stav zásob,

- ztráty,

- dobu cyklu

- teploty a další.

Power BI tedy není určeno jen pro top management a analýzy obchodu, je vhodné například i pro mistry, kteří potřebují sledovat či vytvářet každodenní reporty zobrazující plnění denních norem.

\section{$3 \quad$ Prípadová studie}

Ve studií sledovaném podniku současný stav vypadal tak, že $v$ prípadě, že pokud nějaký pracovník chtěl vyhodnotit poruchy, musel si ze systému vyexportovat data, která se stáhla ve formátu .xlsx. Uvnitř souboru se pak nachází tabulka, která obsahuje sloupce s informacemi o: ID stroje, Času poruchy, informaci, v jaké směně byla porucha zaznamenána a kým, popis 
poruchy, dále pak kdo se poruchou zabýval, kdy ji vyřešil, jak ji vyřešil a podobně. $V$ oddělené tabulce pak byla dodána jména pracovníků a jejich pozice. Jakékoliv analýzy byly prováděny až doposud v excelu a vždy nanovo.

Cílem bylo vytvořit interaktivní nástroj, který umožní po nahrání zdrojového excelu vytvořit analýzy poruch ve směnách, na strojích na zařízeních a podobně.

\section{Řešení v Power BI}

Řešení je vytvořeno tak, že uživatel vezme aktuální soubor vygenerovaný ze systému a nahraje jej do předem definované složky. Power BI si pak do této složky samo automaticky šáhne a vezme nejnovější nahraný soubor. Tento soubor pak zkombinuje stabulkou, která obsahuje jména a pozice zaměstnanců. Na základě těchto dat se vygeneruji automaticky všechny předem definované grafy, prưřezy a menu.

Power BI umožňuje také přímé připojení $k$ datům informačního systému, které však již vyžaduje spolupráci s IT oddělením podniku. Vzhledem $k$ tomu, že námi vytvořené řešení mělo být nezávislé, bez konektorů, $k$ IS, a bylo proto vytvořeno pouze $v$ této jednodušší formě. Celá práce na analýzách zabrala cca 8 hodin.

Vytvořené řešení v Power BI přivítá uživatele vstupním menu, pomocí kterého se může zorientovat a vybrat směr, kam se chce podívat. Na výběr má ze: Směny, Poruchovost zařízení, Nahlášené závady od zaměstnanců, Vyřízené poruchy a specifické poruchy zařízení. Při kliknutí na některou z navigačních ikon je uživatel premístěn na list s př́slušnou analýzou. Pojd'me se nyní na některé podívat.

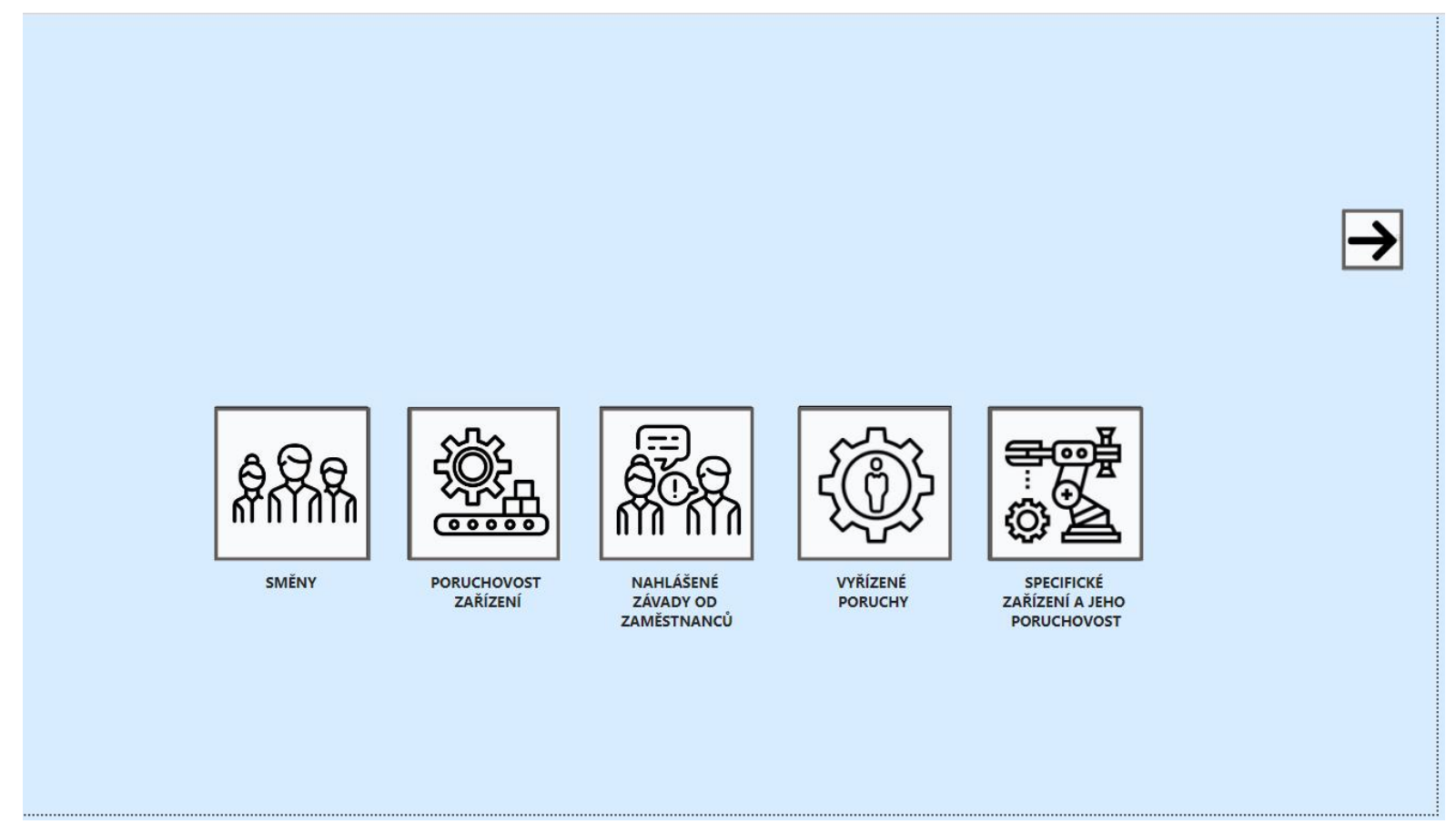

Obrázek 3 - Navigační panel analýzy (Zdroj: vlastní zpracování) 


\section{Směny}

Na kartě „Směny“ uživatel nalezne informace o tom, jak poruchy na strojích vznikají a jsou vyřizovány $v$ průběhu směn. Lze si zde vyfiltrovat jednotlivé směny, pozice a období, ve kterém byly poruchy zaznamenány. $V$ pravém horním rohu je pak navigační panel. Zde stojí zato dodat, že všechny grafy jsou interaktivní a při kliknutí reagují a Ize $v$ nich hierarchicky přejít od pozice $\mathrm{k}$ jednotlivým zaměstnancům, mající tuto pozici.

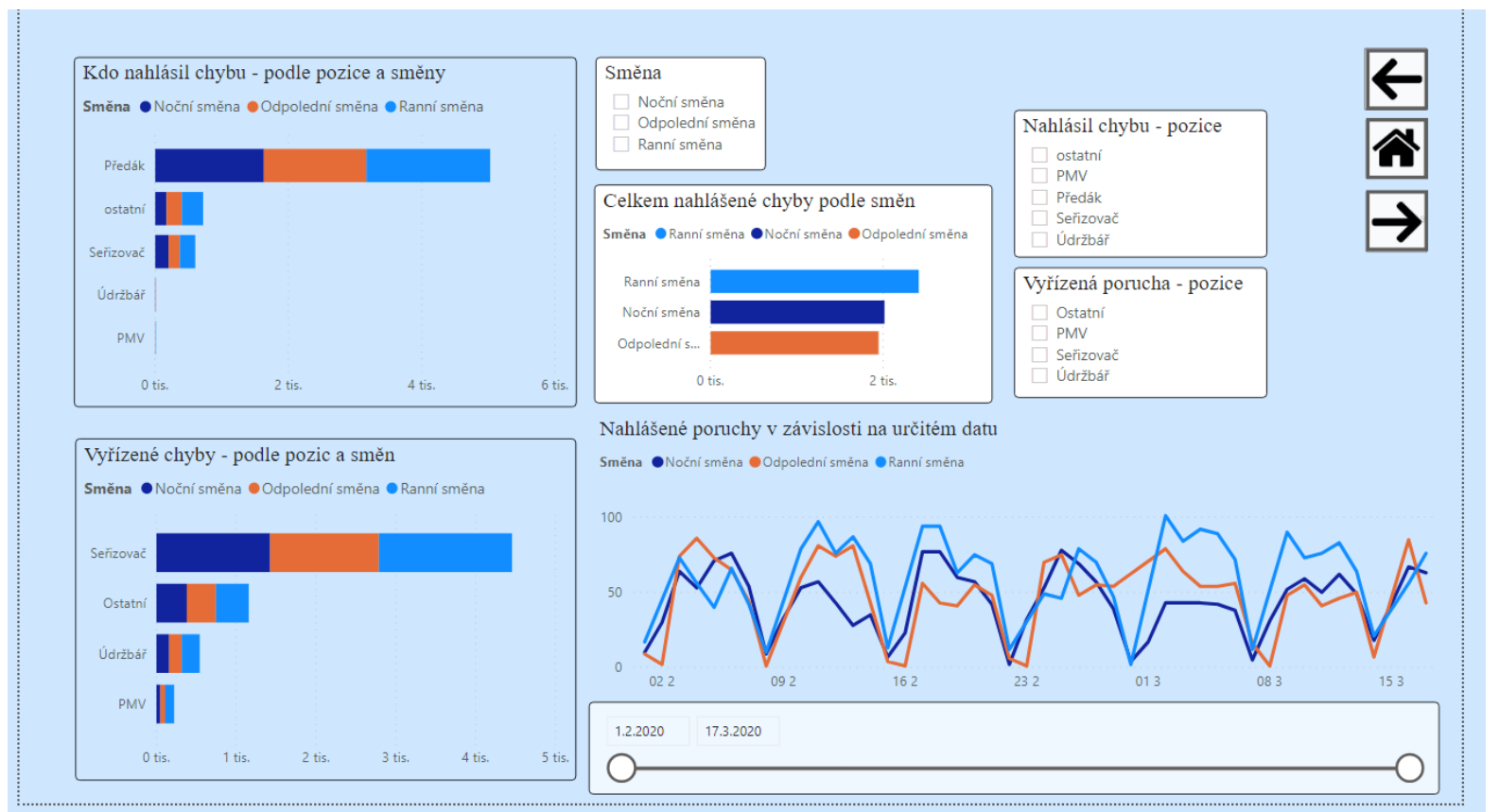

Obrázek 4 - Směny (Zdroj: vlastní zpracování)

\section{Poruchovost zařizení}

Na kartě „Poruchovost zařízeni““ se sledují poruchy ve vztahu k jednotlivým strojům. Grafy sledují počet poruch 10 nejporuchovějších strojů, dále pak počet hodin oprav jednotlivých strojů. $V$ grafu dole je pak srovnání, počet poruch ku času, kdy jsou stroje opravovány. Vše je opět interaktivní a Ize vztáhnout ke specifickému období. 


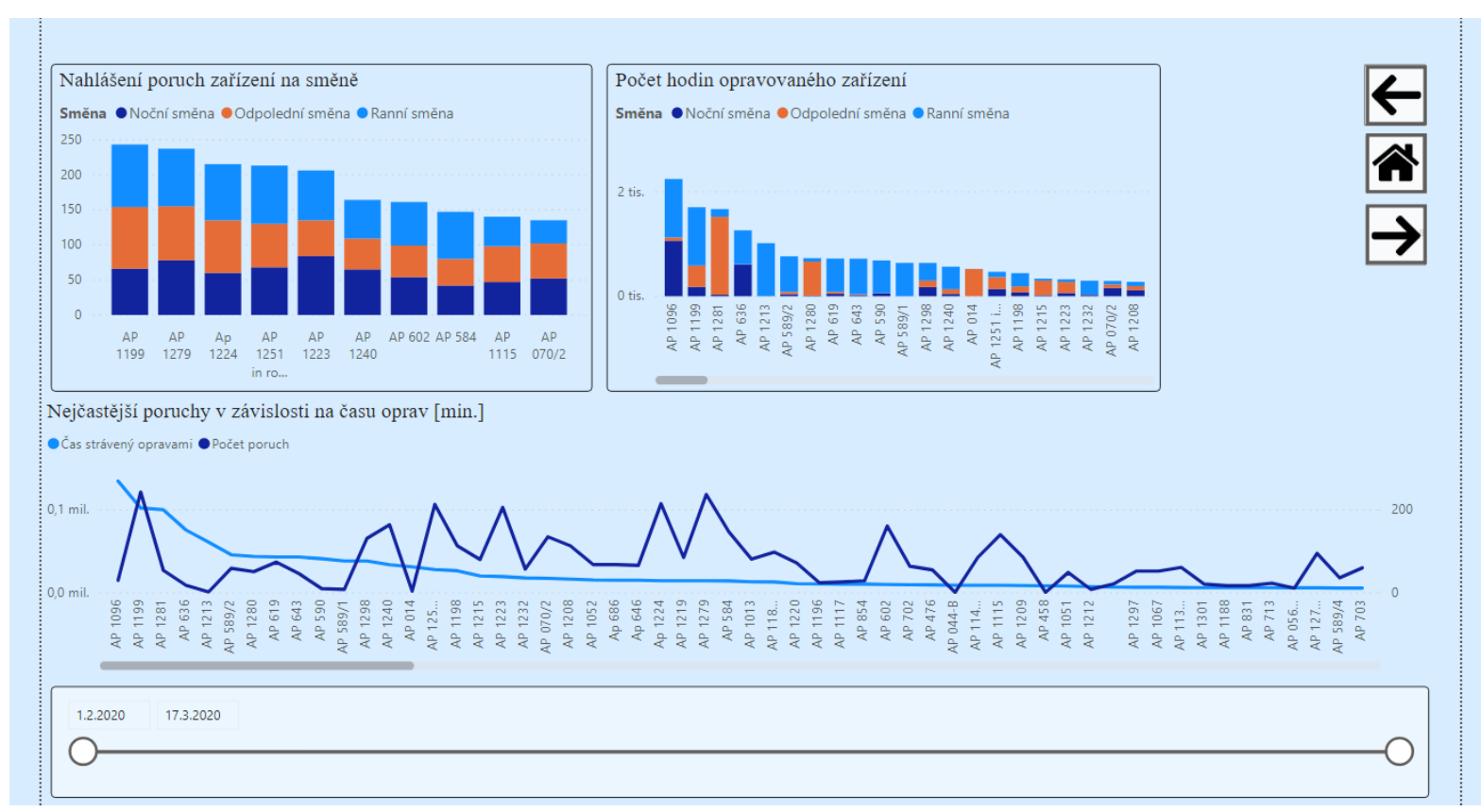

Obrázek 5 - Poruchovost zařizení (Zdroj: vlastní zpracování)

\section{Specifické zařizení a jeho poruchy}

$\checkmark$ posledním listu, který si zde ukážeme, se zaměstnanec může podívat na poruchovost specifického stroje. Zobrazí si počet poruch, jejich jednotlivé i celkové trvání, datum a jejich popis. Vše je opět interaktivní.

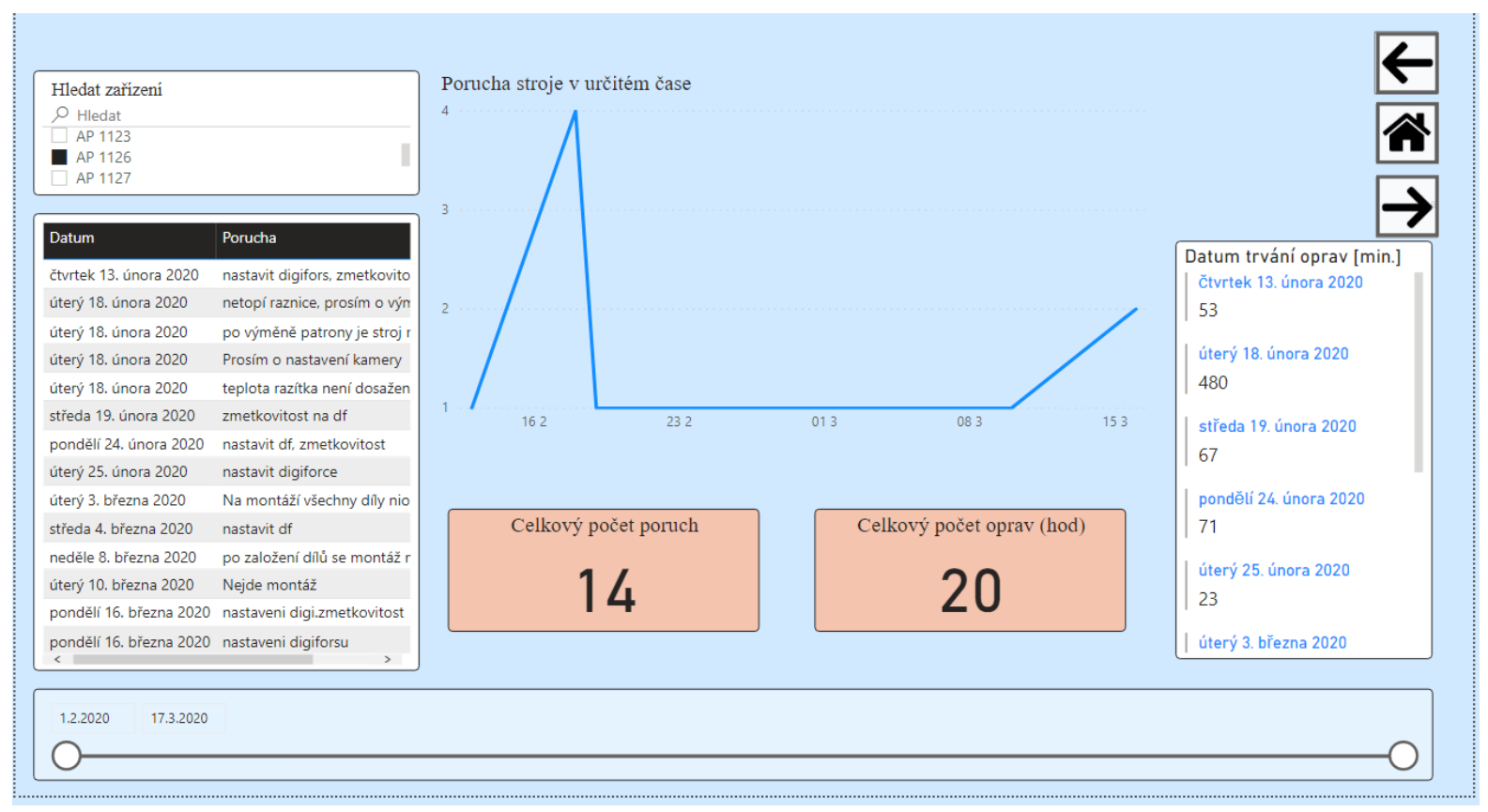

Obrázek 6 - Specifické zařízení a jeho poruchy (Zdroj: vlastní zpracování) 


\section{Závěr}

Tento článek se zaměřil na představení možnosti využití Power BI v průmyslovém podniku, a sice pro analýzu poruch strojů ve výrobě. Článek nejprve představil Power $\mathrm{BI}$ a následně prezentoval jeho využít na prípadové studii. Tato studie slouží jako ukázka, jak je možné využít Power BI pro automatizované analýzy a reporting dat získávaných z různých zdrojů. Jednoznačnou výhodou Power BI je jeho interaktivita a atraktivní vizualizace dat, které $v$ Excelu nelze provádět $s$ takovou efektivitou. Lze očekávat, že $\checkmark$ blízké budoucnosti najde Power $\mathrm{BI}$ uplatnění $v$ mnohých průmyslových podnicích [4].

\section{Poděkování}

Tento článek byl vytvořen za podpory interního grantu Západočeské univerzity číslo projektu je SGS-2018-031 s názvem Optimalizace parametrů udržitelného výrobního systému.

\section{Použitá literatura}

[1] Dokumentace k Power BI [online] 2020. Dostupné z: https://docs.microsoft.com/cs-cz/power-bi/

[2] Dokumentace k Power BI [online] 2020. Dostupné z: https://info.microsoft.com/ww-landing-2020-gartner-magic-quadrant-foranalytics-and-business-intelligence.html?LCID=EN-US

[3] Dokumentace k Power BI [online] 2020. Dostupné z: https://docs.microsoft.com/cs-cz/power-bi/fundamentals/power-bi-overview

[4] Power BI for Manufacturing. [online] QGate Software Ltd, 2020 [cit. 5.3.2020]. Dostupné z: https://www.qgate.co.uk/solutions/ms-powerbi/powerbi-industries/power-bi-manufacturing/ 